\title{
PROGRAM OPSI SAHAM DAN PERILAKU PENGAMBILAN RISIKO MANAJEMEN: PENGUJIAN MEDIASI MODERASIAN
}

\author{
ETIK KRESNAWATI \\ ANANG ALWY SHIHAB \\ NURUL HIDAYATI \\ Universitas Muhammadiyah Yogyakarta, Jl. Brawijaya, Geblagan, Tamantirto, Kec. Kasihan, Bantul, Daerah \\ Istimewa Yogyakarta 55183, Indonesia \\ e_kresna@yahoo.com
}

\begin{abstract}
The management stock option program (POSM) is a type of equity compensation that is theoretically predicted to encourage risk alignment between management and principals, which in turn will encourage goal alignment. This study examines this argument on companies that adopted POSM during the period 1999-2016. Utilizing moderated mediation model, we find that management team's risk taking behavior mediate the effect of POSM on company performance as measured by ROA, but not so when performance is measured by ROE and stock performance index. We also provide evidence that management team considers the company's capital structure, measured by the level of debt, in their risky policy making. Overall, our study documents the critical role of management team's risk behavior to encourage goal alignment between management and principals.
\end{abstract}

Keywords: POSM, risk taking behavior, capital structure, performance

Abstrak: Program opsi saham manajemen (POSM) adalah jenis kompensasi ekuitas yang secara teoritis diprediksi akan mendorong penyelarasan risiko antara manajemen dan para pelaku, yang pada gilirannya akan mendorong penyelarasan tujuan. Studi ini menguji argumen ini pada perusahaan yang mengadopsi POSM selama periode 1999-2016. Dengan menggunakan model mediasi yang dimoderasi, kami menemukan bahwa perilaku pengambilan risiko oleh tim manajemen memediasi efek POSM pada kinerja perusahaan yang diukur dengan ROA, tetapi tidak demikian ketika kinerja diukur dengan ROE dan indeks kinerja saham. Kami juga memberikan bukti bahwa tim manajemen mempertimbangkan struktur modal perusahaan, diukur dengan tingkat utang, dalam pembuatan kebijakan berisiko mereka. Secara keseluruhan, penelitian kami mendokumentasikan peran penting dari perilaku berisiko tim manajemen untuk mendorong penyelarasan tujuan antara manajemen dan kepala sekolah.

Kata kunci: POSM, perilaku ambil risiko, struktur modal, kinerja

\section{PENDAHULUAN}

Pada tahun 2002, Badan Pengawas Pasar Modal (BAPEPAM) melakukan studi terkait penerapan ESOP Emiten atau
Perusahaan Publik di Pasar Modal Indonesia. Beberapa temuan dari studi tersebut diantaranya adalah bahwa perusahaan yang telah melaksanakan program opsi saham karyawan (POSK) merasakan manfaat berupa 
peningkatan kinerja perusahaan dan penyelarasan kepentingan manajemen dan pemegang saham (BAPEPAM, 2002: 82). Studi yang dilakukan BAPEPAM dilandasi dengan asumsi bahwa sebagai bagian dari komunitas dunia, praktik manjemen perusahaan yang terdaftar di Bursa Efek Jakarta (BEJ, sekarang Bursa Efek Indonesia/BEl) kemungkinan akan dipengaruhi praktik yang terjadi di negara lain. Salah satunya adalah kebijakan pengadopsian POSK, sebuah program yang lazim diterapkan oleh perusahaan-perusahaan di negara maju.

Asumsi BAPEPAM tersebut diperkuat oleh berbagai penelitian empiris terkait manfaat POSK di Indonesia yang dilakukan oleh, misalnya Anwar (2006), Astika (2007), Kresnawati (2009), Wiratma dan Kristanto (2010), yang menunjukkan peningkatan jumlah sampel perusahaan yang terdaftar di BEl yang mengadopsi POSK. Sementara di Amerika, Hall dan Murphy (2002) menunjukkan bahwa pada tahun fiskal 1999, 94\% dari 500 perusahaan S\&P menghibahkan opsi saham kepada eksekutif. Meningkat 82\% dibanding tahun 1992. Demikian juga hasil survei The National Center for Employee Ownership tahun 2002 yang menunjukkan bahwa lebih dari $25 \%$ dari seluruh perusahaan publik di Amerika menyediakan opsi untuk hampir semua karyawan penuh-waktu (NCEO, 2010). Peningkatan jumlah perusahaan yang mengadopsi POSK secara tidak langsung mengisyaratkan bahwa perusahaan berhadap atau bahkan telah merasakan manfaat dari POSM.

POSK adalah program insentif non kas yang memberi hak kepada penerimanya (karyawan) untuk membeli saham perusahaan tempat mereka bekerja pada waktu, jumlah, dan harga tertentu yang ditetapkan sebelumnya. Program opsi saham karyawan adalah salah satu bentuk kompensasi ekstrinsik yang diberikan kepada kayawan. Kompensasi ini termasuk jenis kompensasi jangka panjang selain hibah saham (stock grants), pembelian saham oleh karyawan secara langsung (direct employee stock purchase plans), program kepemilikan saham karyawan (employee stock ownership plan/ESOP), saham semu (phantom stock) dan hak apresiasi saham (stock appreciation rights).

Secara teori, pembahasan tentang program opsi saham yang diberikan kepada karyawan mulai berkembang setelah dibangun model formal hubungan keagenan oleh Jensen dan Meckling (1976), yang kemudian lebih dikenal dengan teori keagenan. Dalam model tersebut, Jensen dan Meckling mengeksplorasi berbagai kemungkinan struktur kepemilikan di perusahaan dan imbasnya terhadap kesejahteraan pemegang saham (prinsipal). Teori keagenan memprediksi bahwa perusahaan yang di dalamnya terdapat pemisahan antara prinsipal dengan manajer (agen), sangat mungkin mengalami konflik keagenan karena diasumsikan ada perilaku selfinterest manajer, asimetri informasi, dan perbedaan preferensi risiko antara prinsipal dan manajer (Jensen dan Meckling, 1976; Eisenhardt, 1989). Perilaku tersebut akan berimbas pada tindakan manajer yang mengambil kebijakan pengelolaan perusahaan yang tidak memaksimalkan kepentingan prinsipal. Oleh karen itu perlu disusun kontrak optimal antara keduanya yang akan mengikat utilitas ekspektasian agen dengan kesejahteraan prinsipal.

Argumen yang dikemukakan oleh Jensen dan Meckling (1976) tentang keefektifan kompensasi dalam bentuk opsi saham didasarkan pada asumsi ketidakselarasan preferensi risiko manajemen dengan prinsipal. Artinya, goal congruance yang menjadi tujuan program ini akan tercapai kalau ada keselarasan preferensi tersebut. Oleh karena itu, pengujian terhadap keefektifan program opsi saham selayaknya dilakukan pada level manajerial selaku pembuat kebijakan pengelolaan perusahaan.

Hasil penelitian yang menguji perilaku pengambilan risiko penerima opsi saham berargumen bahwa POSK/M akan mengubah perilaku pengambilan risiko penerimanya 
(Huddart dan Lang, 1996; Guay, 1999; Sautner dan Weber, 2005; Bettis et al., 2005). Temuan penting dari penelitian-penelitian tersebut adalah sebagai berikut: Pertama, pemberian opsi mengubah perilaku penerimanya menjadi kurang penghindar-risiko yang ditandai dengan pengambilan kebijakan yang lebih berisiko seperti lebih banyak mengeluarkan biaya untuk R\&D dan akuisisi. Kedua, karyawan level yang lebih tinggi (top level) mempunyai kebersediaan lebih besar untuk menanggung risiko dibanding karyawan pada level yang lebih rendah (lower level). Hal ini ditunjukkan dengan kebersediaan mereka untuk lebih lama memegang saham hasil penggunaan opsi. Hasil penelitian di atas mengisyaratkan bahwa program opsi saham akan efektif untuk mengubah preferensi risiko pada kelompok karyawan level atas. Hanya saja penelitian pada kelompok ini tidak menghubungkannya dengan kinerja perusahaan. Berdasarkan hasil penelitian tersebut, penelitian ini akan menguji keefektifan POSK pada level manajerial (POSM).

Sementara itu, penelitian di Indonesia yang menghubungkan POSK dengan kinerja perusahaan tidak menunjukkan hasil uji seperti yang diprediksi teori. Penelitian Anwar (2006), Astika (2007), Kresnawati (2009), dan Wiratma dan Kristanto (2010) menunjukkan bahwa POSK tidak berpengaruh terhadap kinerja saham maupun ROE, tetapi berpengaruh negatif terhadap ROE setelah tanggal hibah. Hal ini dapat dapat diartikan bahwa tidak ada penyelarasan kepentingan antara agenprinsipal. Sementara hasil penelitian yang dilakukan di luar negeri menunjukkan hasil yang beragam. Hanlon et al. (2003), Kato et al. (2005), Hutchinson dan Gul (2006) menyimpulkan bahwa POSM meningkatkan kinerja perusahaan setelah tanggal hibah, sementara penelitian Abdelaziz et al. (2011) menunjukkan bahwa tidak ada perubahan signifikan atas kinerja akuntansi perusahaan pada perioda satu tahun setelah hibah.

Berdasarkan hasil penelitian sebelumnya yang tidak konklusif, Kresnawati et al. (2016) menguji keefektifan POSM alih-alih POSK dengan asumsi bahwa keefektifan POSM tidak tepat kalau diuji secara langsung, melainkan harus melihat apakah program tersebut direspon oleh penerimanya dalam bentuk kebersediaan untuk menanggung risiko perusahaan. Kebersediaan menanggung risiko ini yang selanjutnya diharapkan akan berdampak pada pengambilan kebijakan pengelolaan perusahaan yang akan menciptakan goal congruance, yang ditandai dengan kenaikan kinerja perusahaan. Hasil pengujian mendukung hipotesis yang diajukan bahwa POSM mendorong kenaikan kinerja perusahaan ketika tim manajemen (TM) sebagai penerima POSM bersedia menanggung risiko perusahaan dalam bentuk menggunakan hak opsi sahamnya.

Pengambilan kebijakan manajemen dalam mengelola perusahaan tentu tidak dapat dilepaskan dari kondisi perusahaan. Kim et al. (2017) menunjukkan bahwa struktur modal mempengaruhi pengaruh positif insentif dalam bentuk opsi saham dan pengambilan risiko CEO. Struktur modal yang diukur dengan tingkat utang (leverage), secara teori adalah sarana pemonitoran pihak eksternal (kreditur) terhadap tindakan dan kinerja manajemen. Tingkat utang yang tinggi menandai kecenderungan financial distress, pelanggaran kontrak keuangan, kegagalan utang, bahkan kebangkrutan. Hasil pengujian Kim et al. (2017) menunjukkan bahwa tingginya tingkat utang akan menurunkan hasrat pengambilan risiko CEO yang memperoleh insentif dalam bentk opsi saham.

Berdasarkan uraian dia atas, penelitian ini bertujuan untuk menguji ekspektasi teori seperti yang dikemukan oleh Jensen dan Meckling (1976) bahwa pemberian kompensasi dalam bentuk ekuitas (opsi saham) akan mendorong penyelarasan preferensi dan tindakan manajemen dalam mengelola perusahaan dengan memperhatikan kondisi internal perusahaan yaitu struktur modal (Kim et al., 2017). Penelitian ini melanjutkan penelitian Kresnawati et al. (2016) yang menguji 
keefektifan program opsi saham manajemen (POSM) melalui kebersediaan manajemen dalam menanggung risiko perusahaan yang dimoderasi dengan munculan masa lalu. Model penelitian tersebut belum mengakomodasi aktivitas pengelolaan berisiko sebagai bentuk penyelarasan risiko antara manajemen dan prinsipal. Peneliti baru baru menguji perilaku berisiko TM yang ditandai dengan kebersediaan TM menanggung risiko perusahaan dengan menggunakan hak opsi sahamnya. Melanjutkan model pengujian tersebut, dalam penelitian ini, penulis bertujuan untuk menguji apakah kebersediaan TM menanggung risiko perusahaan dengan menggunakan hak opsi sahamnya akan memengaruhi kebijakan pengelolaan berisiko yang diambil yang selanjutnya akan mendorong peningkatan kinerja.

Penulis juga akan menggunakan struktur modal sebagai variabel pemoderasi pengaruh POSM dan perilaku pengambilan risiko manajemen dengan merujuk pada hasil penelitian Kim et al. (2017). Ketika manajemen dihadapkan pada pengambilan keputusan yang berisiko, ada hal-hal yang perlu dipertimbangkan oleh manajemen, salah satunya adalah kondisi internal perusahaan terkait struktur modal yang dimiliki perusahaan. Keleluasaan manajemen dalam berinvestasi, yang di dalamnya mengandung risiko, akan dibatasi ketika struktur modal didominasi oleh utang. Keberadaan utang sebagai mekanisme kontrol eksternal akan menahan perilaku pengambilan risiko berlebih dari manajemen dalam mengelola perusahaan.

Penelitian ini diharapkan memberi kontribusi secara teoretis dan metodologi. Secara teoretis, penelitian ini mengkonfirmasi hasil penelitian terdahulu yang menguji keefektifan kompensasi ekuitas berdasarkan argumen teori keagenan pada tatanan (setting) yang berbeda, yaitu POSM. Dari sisi metoda penelitian, penelitian ini memberi kontribusi dalam model pengujian yaitu dengan model mediasi moderasian. Model ini dapat menjelaskan proses keefektifan POSM yang mensyaratkan penyelarasan perilaku risiko manajemen dalam bentuk pengambilan kebijakan perusahaan yang berisiko (Jensen dan Meckling, 1976). Model pengujian ini menjadi penting karena bila ternyata POSM tidak mempengaruhi perilaku pengambilan risiko penerima opsi untuk menjadi lebih pengambilrisiko, sangat kecil kemungkinan bahwa POSM akan mendorong peningkatan kinerja perusahaan. Hal ini yang tidak tereksplorasi dalam pengujian dengan model langsung (Hanlon et al., 2003; Kato et al., 2005; Hutchinson dan Gul, 2006; Defusco et al., 1991).

\section{Teori Keagenan}

Secara spesifik, teori keagenan mengulas tentang kontrak yang didalamnya satu atau lebih orang (prinsipal) mendelegasikan tugas pengelolaan perusahaan kepada pihak lain (agen/manajer) untuk bertindak atas namanya. Tanggung jawab utama manajer dalam hal ini adalah melindungi kepentingan dan meningkatkan kesejahteraan prinsipal (Jensen dan Meckling, 1976). Namun demikian, tidak sepenuhnya diyakini bahwa manajer akan bertindak untuk kepentingan terbaik prinsipal karena manajer juga mempunyai kepentingan untuk memaksimalkan kesejahteraanya.

Dengan menggunakan metafora kontrak, teori keagenan mencoba menjelaskan dua masalah yang dapat terjadi dalam hubungan keagenan (Fama, 1980). Pertama, masalah ketidakselarasan kepentingan/tujuan. Asumsi yang melandasi konflik ini adalah adanya asimentri informasi yang dapat mendorong manajer untuk melakukan tindakan yang bersifat moral hazard dan/atau adverse selection. Kedua, masalah penyelarasan risiko yang muncul ketika pemegang saham dan manajer mempunyai preferensi yang berbeda terhadap risiko. Ketidakselarasan kepentingan dan sikap terhadap risiko akan berimbas pada munculnya konflik keagenan, yaitu ketika prinsipal harus menanggung kos atas tindakan manajer yang tidak menghasilkan tingkat kembalian memadai karena yang bersangkutan 
lebih banyak mencurahkan upaya pengelolaan untuk meningkatkan ukuran perusahaan tanpa mempertimbangkan risiko jangka panjang (Tossi et al., 2000).

Untuk meminimalkan kos keagenan, prinsipal berupaya menurunkan kemungkinan ketidakselarasan kepentingan dengan cara, salah satunya, mendesain kontrak kompensasi yang dianggap efisien. Kontrak kompensasi dikatakan efisien jika kontrak tersebut disepakati oleh pihak-pihak yang berkontrak dengan tingkat pembagian risiko tertentu dan memungkinkan pemonitoran langsung oleh pemegang saham terhadap semua upaya manajer (Scott, 2006). Prinsipal dapat mendesain kontrak kompensasi yang menyeimbangkan antara insentif dan risiko manajer. Oleh karena kepemilikan ekuitas oleh manajer dipandang akan menyelaraskan kepentingan manajer dengan prinsipal (Jensen dan Meckling, 1976), maka komponen kompensasi akan lebih baik jika tidak hanya berisi komponen moneter (gaji dan bonus moneter) tetapi juga komponen ekuitas. Komponen moneter umumnya terikat pada munculan yang diupayakan oleh manajer yang tercermin pada laba pelaporan, sedangkan komponen ekuitas terikat pada harga saham perusahaan.

\section{Teori Upper Ecelon}

Kepemimpinan dalam organisasi yang komplek sering mensyaratkan CEO untuk mendelegasikan tanggungjawab kepada kepala divisi (fungsi) di organisasi sebagai sebuah tim yang saling tergantung (interdependent) (Hambrick, 1995). Masing-masing mempunyai tugas, kognisi, kemampuan dan perilaku yang berbeda. Upper echelon theory (Hambrick dan Mason, 1984; Hambrick, 2007) menjelaskan bahwa mempertimbangkan peran grup eksekutif, alih-alih hanya individu CEO akan memberi penjelasan yang lebih baik terhadap munculan organisasi.

Penelitian ini menggunakan sampel perusahaan yang terdaftar di BEl yang mengadopsi POSM. Sepengetahuan penulis, tidak ada perusahaan di BEl yang hanya memberi opsi saham kepada CEO (direktur utama) ketika mengadopsi POSK. Kebijakan ini mungkin didasari argumen bahwa pada praktiknya CEO bukan pemain tunggal dalam menentukan strategi perusahaan. Walaupun CEO mempunyai sifat tugas dan tanggung jawab yang secara substansial berbeda dengan level manajemen puncak lainnya, namun keduanya sama-sama menjadi penentu penting strategi perusahaan dalam lingkungan yang bergejolak (Henderson et al., 2006). Pemilihan hanya POSM dan bukan POSK juga didasari argumen bahwa tindakan jajaran manajemen puncak lebih mempunyai pengaruh terhadap kinerja perusahaan dibanding level yang lebih rendah (Hanlon et al., 2003).

\section{Pengaruh Struktur Modal pada Hubungan POSM dan Perilaku Risiko Manajemen}

Masalah yang melekat pada argumen penyelarasan kepentingan adalah penyelarasan perbedaan preferensi risiko antara manajemen dengan pemegang saham. Salah satu alasan penting memasukkan komponen opsi saham dalam skema kompensasi kepada manajemen adalah bahwa kompensasi manajemen tanpa komponen berbasis-ekuitas akan membuat manajemen memfokuskan pada pelaporan laba akuntansi jangka pendek, khususnya pada stabilitas jangka pendek, untuk mengamankan kesejahteraannya. Hibah opsi saham kepada manajemen adalah sarana yang diharapkan akan mengubah perilaku pengambilan risiko penerimanya karena akan mengubah peran manajer, tidak lagi hanya sebagai pengelola tetapi sekaligus pemilik perusahaan (Jensen dan Meckling, 1976).

Sitkin dan Pablo (1992), mengikuti Kahneman dan Tverski (1979), mendefinisi perilaku risiko sebagai perilaku individual dalam pengambilan keputusan pada kondisi yang berisiko yang dicirikan dengan tingkat risiko dikaitkan dengan keputusan yang dibuat. Lebih lanjut, Sitkin dan Pablo menyatakan bahwa keputusan dikatakan lebih berisiko ketika: (1) 
munculan ekspektasian lebih tidak pasti, (2) tujuan dari keputusan yang dibuat lebih sulit untuk dicapai, dan (3) set munculan potensial menyertakan konsekuensi ekstrem. Terkait dengan perilaku pengambilan risiko TM dalam POSM, secara lebih spesifik penelitian ini mendefinisi perilaku pengambilan risiko TM sebagai perilaku pengambilan keputusan TM terkait dengan penggunaan opsi saham yang dimilikinya. Perilaku tersebut dikatakan semakin berisiko ketika TM mengambil kebijakan pengelolaan perusahaan yang secara teori melibatkan risiko. Pada umumnya prinsipal menghendaki manajer untuk memaksimumkan return perusahaan. Dengan asumsi bahwa return yang lebih besar akan dihasilkan pada tingkat risiko yang lebih tinggi (Sharpe, 1970), harapannya adalah manajemen akan bersedia mengambil kebijakan pengelolaan perusahaan dalam bentuk kebijakan pada tingkat risiko tertentu. Bukan sebaliknya, justru yang menghindari atau menghilangkan risiko untuk kepentingan jangka pendek akan mempengaruhi besarnya return bagi prinsipal.

Pengambilan kebijakan manajemen dalam mengelola perusahaan tentu tidak dapat dilepaskan dari kondisi perusahaan. Kim et al. (2017) menunjukkan bahwa struktur modal memengaruhi pengaruh positif insentif dalam bentuk opsi saham dan pengambilan risiko CEO. Struktur modal yang diukur dengan tingkat utang (leverage), secara teori adalah sarana pemonitoran pihak eksternal (kreditur) terhadap tindakan dan kinerja manajemen. Tingkat utang yang tinggi menandai kecenderungan financial distress, pelanggaran kontrak keuangan, kegagalan utang, bahkan kebangkrutan. Hasil pengujian Kim et al. (2017) menunjukkan bahwa tingginya tingkat utang akan menurunkan hasrat pengambilan risiko CEO yang memperoleh insentif dalam bentuk opsi saham.

Dengan demikian, kebijakan berisiko yang diambil manajemen dalam mengelola perusahaan tidak bisa dilepaskan dari kondisi lain seperti struktur modal perusahaan. Bila struktur modal didominasi oleh utang kepada pihak eksternal (kreditur), pemonitoran oleh kreditur terhadap kebijakan pengelolaan perusahaan juga akan semakin tinggi. Oleh karena itu, semakin tinggi tingkat utang perusahaan, diprediksi akan menurunkan perilaku berisiko manajemen. Berdasar argumen tersebut, hipotesis pertama dalam penelitian ini adalah:

H1: Pengaruh positif POSM terhadap perilaku risiko TM akan semakin kecil pada perusahaan yang tingkat utangnya semakin tinggi.

\section{Pengaruh Perilaku Risiko Tim Manajemen terhadap Kinerja Perusahaan}

Paradigma awal yang menjelaskan keterkaitan antara perilaku pengambilan risiko dengan munculan teori portofolio modern (Hartono, 2007). Teori ini mengasumsikan bahwa investor adalah rasional dan pasar adalah efisien. Konsep fundamental dari teori ini adalah bagaimana menginvestasikan aset dalam portofolio yang memberi return ekspektasian terbesar dengan tingkat risiko yang sudah pasti atau portofolio dengan risiko terkecil dengan return ekspektasian yang sudah pasti. Secara umum dapat dikatakan bahwa investasi adalah tradeoff antara risiko dan return ekspektasian.

Pengadopsian POSM adalah program yang diuslkan oleh tim remunerasi yang didalamnya melibatkan manajemen. Ketika usulan tersebut disetujui oleh pemegang saham, tentu ada konsekuensi yang harus dibayar. Yang paling lazim adalah harapan peningkatan kinerja seperti hasil survei BAPEPAM (2002). Dengan demikian, ketika TM sudah bersedia untuk menanggung risiko perusahaan dengan menggunakan hak opsinya, maka kedudukan mereka automatis juga sebagai pemilik perusahaan. Kebijakan pengelolaan perusahaan semestinya tidak hanya dilihat sebagai pengelola tetapi juga sebagai pemilik. Berdasarkan argumen ini, penulis menduga bahwa kebijakan pengelolaan berisiko yang diambil oleh manajemen seharusnya sudah 
dengan memperhitungkan tingkat risko tertentu yang diharapkan akan menghasilkan return terbesar. Hipotesis 2 terkait hubungan ini adalah sebagai berikut:

H2: Perilaku risiko TM berpengaruh positif terhadap kinerja perusahaan

\section{Pengaruh Tidak Langsung POSM terhadap Kinerja Perusahaan melalui Perilaku Risiko TM dengan Struktur Modal sebagai pemoderasi}

Argumen dalam teori keagenan bahwa kompensasi ekuitas akan menyelaraskan kepentingan antara pemilik dengan manajer, secara implisit bukanlah hubungan langsung. Jensen dan Meckling (1976) mengisyaratkan bahwa penyelarasan ini akan lebih baik karena kompensasi ekuitas, yang mempunyai horizon waktu jangka panjang, akan mensejajarkan kedudukan manajer dengan pemilik yaitu sebagai pemegang saham perusahaan. Manajer yang diasumsikan adalah penghindar-risiko diharapkan akan terdorong untuk lebih berani mengambil risiko dalam upaya menghasilkan return yang lebih besar. Artinya, penyelarasan kepentingan yang ingin dicapai melalui kompensasi ekuitas dalam bentuk POSM adalah hasil dari penyelarasan risiko antara manajer dengan pemegang saham.

Penelitian yang menguji hubungan langsung antara program opsi saham dengan kinerja perusahaan tidak memberi informasi penyelarasan risiko, yaitu apakah POSM mendorong penerimanya untuk lebih berani menanggung risiko perusahaan. Ketika POSM gagal menyelaraskan perilaku pengambilan risiko TM dan prinsipal, kecil kemungkinan bahwa program ini akan mendorong peningkatan kinerja perusahaan. Prediksi ini akan terjawab bila diuji dengan melibatkan variabel pemediasi, yaitu perilaku pengambilan risiko TM.

POSM adalah salah satu bentuk kompensasi jangka panjang yang diharapkan akan memberi insentif bagi penerimanya untuk menyelaraskan perilaku pengambilan risiko TM dengan prinsipal dengan cara mendorong TM untuk lebih berani mengambil kebijakan pengelolaan perusahaan yang lebih berisiko pada tingkat return tertentu yang lebih tinggi. Dengan mendudukkan TM sebagai pengelola sekaligus pemilik perusahaan (manajer-pemilik), diharapkan bahwa yang bersangkutan akan membuat kebijakan pengelolaan perusahaan yang juga akan menguntungkan prinsipal-non manajer. Ketika semakin besar kesejahteraan TM terikat dengan return perusahaan, diharapkan TM akan mengambil kebijakan pengelolaan perusahaan yang optimal yang akan menguntungkan mereka pribadi maupun prinsipal non-manajer sehinga tercapai goal congruance. Berdasarkan argumen tersebut, dihipotesiskan:

H3: Pengaruh positif POSM terhadap perilaku pengambilan risiko TM akan semakin kecil ketika tingkat utang perusahaan semakin tinggi, yang selanjutnya berpengaruh positif terhadap kinerja perusahaan.

\section{METODA}

Perusahaan yang menjadi sampel dalam penelitian ini adalah seluruh perusahaan yang terdaftar di BEI yang mengadopsi POSK atau POSM mulai tahun 1999-2016. Sampel diambil mulai tahun 1999 karena pada tahun tersebut mulai berlaku PSAK No. 53 yang mengatur tentang kompensasi berbasis ekuitas. POSM yang dimaksud dalam penelitian ini adalah program pemberian opsi saham kepada TM di perusahaan yang mengumumkan POSK/M.

Tim Manajemen dalam penelitian adalah tim manajemen kunci yang dapat terdiri dari komisaris non-independen, direksi dan karyawan kunci perusahaan. Komisaris nonindependen dimasukkan sebagai bagian dari TM karena bertugas mengawasi kebijakan direksi dalam menjalankan perseroan serta memberi nasihat kepada direksi. Dengan demikian, kinerja direksi perusahaan juga ditentukan oleh 
kinerja komisaris dalam mengawasi dan memberi nasihat kepada direksi. Komisaris bahkan dapat digugat ke pengadilan negeri yang karena kesalahan atau kelalaiannya menimbulkan kerugian pada perseroan (UU PT BAB 6 pasal 97). Data dan sumber data yang digunakan dalam pengukuran variabel utama penelitian ini adalah sebagai berikut:

Tabel 1 Data dan Sumber Data

\begin{tabular}{|c|c|c|}
\hline No. & Data & Sumber Data \\
\hline 1. & $\begin{array}{l}\text { Jumlah opsi saham yang dihibahkan } \\
\text { kepada TM }\end{array}$ & $\begin{array}{l}\text { Laporan keuangan tahunan perusahaan, } \\
\text { ringkasan hasil RUPS-LB dan akta } \\
\text { notaris (untuk beberapa perusahaan) }\end{array}$ \\
\hline 2. & Jumlah ops & $\begin{array}{l}\text { Laporan Biro Administrasi Efek, IDX } \\
\text { Statistics }\end{array}$ \\
\hline 3. & $\begin{array}{l}\text { Harga penggunaan opsi, data aset, } \\
\text { utang, ekuitas dan laporan laba rugi }\end{array}$ & Laporan keuangan tahunan perusahaan \\
\hline 4. & $\begin{array}{l}\text { Harga saham dan pembayaran } \\
\text { dividen }\end{array}$ & $\begin{array}{l}\text { PDBE FEB UGM, laporan profil emiten } \\
\text { yang dikeluarkan BEl, Yahoo } \\
\text { finance.com }\end{array}$ \\
\hline
\end{tabular}

Berdasarkan kriteria penyampelan di atas, perusahaan yang digunakan sebagai sampel dalam penelitian ini adalah sebagai berikut:

Tabel 2 Prosedur Penyampelan

\begin{tabular}{lcc}
\hline \multicolumn{1}{c}{ Keterangan } & $\begin{array}{c}\text { Jumlah } \\
\text { Perusahaan }\end{array}$ & $\begin{array}{c}\text { Jumlah } \\
\text { Sampel }\end{array}$ \\
\hline $\begin{array}{l}\text { Perusahaan yang mengumumkan POSK/M } \\
\text { tahun 1999-2016 }\end{array}$ & 48 & 67 \\
$\begin{array}{l}\text { (-) Perusahaan yang perioda penggunaan } \\
\text { opsinya melebihi tahun 2011 }\end{array}$ & 4 & 7 \\
$\begin{array}{l}\text { (-) Perusahaan yang datanya tidak } \\
\text { lengkap, delisting, dan/atau } \\
\text { perdagangan sahamnya tidak likuid }\end{array}$ & 19 & 22 \\
\hline Jumlah sampel yang dapat digunakan & 21 & 38 \\
\hline
\end{tabular}

Model penelitian di bawah ini menunjukkan hubungan variabel yang akan diuji pada hipotesis 1 , 2, 3, dan pengujian ketegaran dengan memasukkan variabel kontrol. 


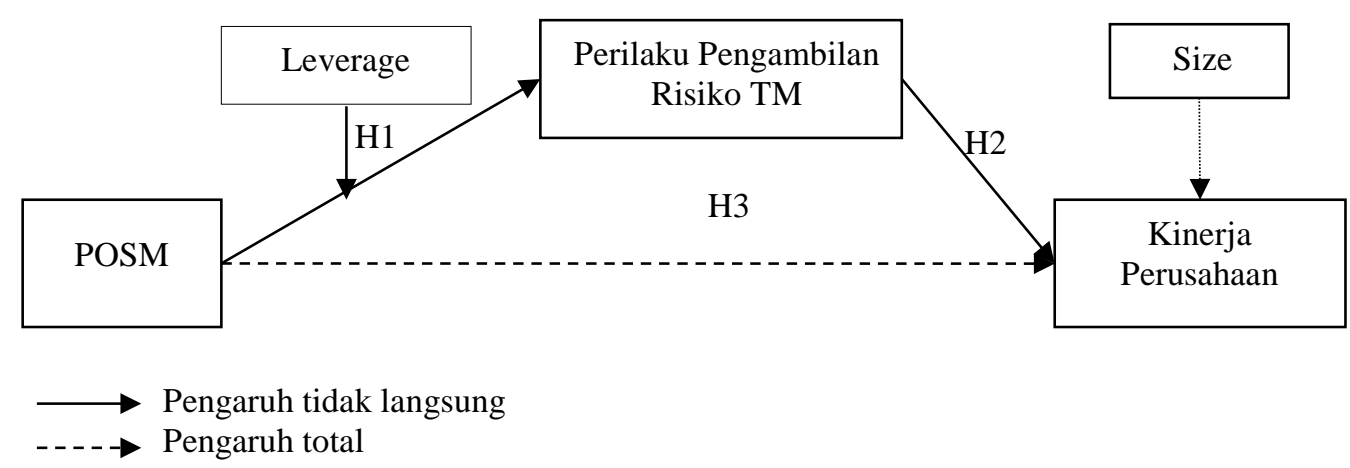

\section{Gambar 1 Model Hubungan Variabel}

Variabel independen dalam penelitian ini adalah POSM. Melanjutkan penelitian Kresnawati et al. (2016), POSM diukur dengan tingkat kebersediaan TM yang menggunakan hak opsi sahamnya dengan rumus proporsi antara jumlah saham hasil penggunaan opsi oleh TM dan jumlah saham yang dihibahkan kepada TM. Angka ini diperoleh dari laporan penambahan saham baru hasil penggunaan POSM yang dilaporkan oleh Biro Administrasi Efek setiap perusahaan. Selanjutnya penulis akan melakukan cek silang dengan data additional listed shares yang dilaporkan dalam IDX Quarterly Statistics.

Variabel dependen dalam penelitian ini adalah Kinerja perusahaan. Penulis menggunakan ukuran kinerja keuangan dan kinerja pasar selama perioda penggunaan opsi saham. Kinerja keuangan setiap perusahaan diukur dengan rerata kinerja pada perioda penggunaan, yaitu rerata ROA (laba bersih dibagi dengan total aset) dan ROE (laba bersih dibagi dengan total ekuitas) pada perioda digunakannya opsi saham manajemen. Secara matematis, kedua ukuran tersebut dirumuskan sebagai berikut:

$$
\begin{aligned}
& R O A_{i, t 3}=\frac{\sum_{t=1}^{n} \frac{\text { laba bersih }_{i}}{\text { total aset }_{i}}}{N} . \\
& R O E_{i, t 3}=\frac{\sum_{t=1}^{n} \frac{\text { laba bersih }_{i}}{\text { total ekuitas }_{i}}}{N} .
\end{aligned}
$$

Kinerja pasar selama perioda penggunaan POSM diukur dengan tingkat pertumbuhan return bulanan (compounded monthly return). Penulis menggunakan return bulanan untuk meningkatan ketepatan pengukuran kinerja pada bulan dimulainya penggunaan POSM. Sementara itu, pengukuran dengan metoda geometrik dipandang lebih tepat karena return pada perioda tertentu adalah angka yang tidak independen dengan return pada perioda sebelumnya. Secara matematis, pengukuran kinerja pasar (return) pada perioda penggunaan POSM dirumuskan sebagai berikut:

$$
\begin{aligned}
& I K K_{i, t 3}=\left(\left(1+R_{1}\right) *\left(1+R_{2}\right) * \ldots \ldots *\right. \\
& \left.\left(1+R_{n}\right)\right)-1 \\
& R_{1}=\left(D_{1}+P_{1}-P_{0}\right) /\left(P_{0}\right) \ldots \ldots \ldots \ldots \ldots \ldots . . .
\end{aligned}
$$

Dalam hal ini,

$\mathrm{IKK}_{\mathrm{i}, \mathrm{t} 3}$ : indeks kinerja kumulatif yang pada perioda penggunaan POSM yang diukur dengan return geometrik.

$\mathrm{R}_{1}, \mathrm{R}_{2} \ldots \mathrm{Rn}$ : return pada bulan ke-1, ke-2...ke$n$ pada perioda penggunaan POSM

$\mathrm{R}_{\mathrm{n}}$ : $\quad$ return pada bulan terakhir perioda penggunaan POSM

D: deviden kas

$\mathrm{P}: \quad$ harga saham. 
Mengikuti Kim et al. (2017), variabel pemoderasi yang digunakan adalah struktur modal yang diukur dengan rasio nilai buku total utang jangka panjang terhadap total aset. Ukuran ini untuk menangkap beban risiko kegagalan dan pemonitoran pemberi pinjaman (kreditur) terhadap manjer yang penghindarrisiko.

Variabel pemediasi dalam penelitian ini adalah perilaku risiko TM yang diukur dengan rasio kas yang dikeluarkan untuk investasi aktiva tetap dengan total aset yang dikeluarkan oleh perusahaan. Pengeluaran ini sifatnya adalah sunk-cost. Semakin besar komponen ini mengisyaratkan bahwa manajemen semakin berani mengambil kebijakan berisiko dalam mengelola perusahaan dengan menamkan modal pada investasi yang belum tentu akan mendapatkan kembalian sesuai prediksi.

Desain penelitian yang digunakan dalam penelitian ini tidak memungkinkan penulis untuk mengendalikan secara langsung terhadap munculan dari setiap variabel yang akan diuji. Untuk memperkecil efek pengganggu (confounding effect) yang mungkin mempengaruhi hubungan dalam model pengujian, penulis memasukkan variabel kontrol yang diduga akan mempengaruhi munculan pada variabel dependen. Fokus utama dari penelitian ini adalah menguji model mediasi moderasian keefektifan POSM dengan menggunakan software process. Salah satu kekurangan software ini adalah tidak memfasilitasi penggunaan variabel kontrol yang berbeda untuk menguji munculan pada semua path pada model mediasi moderasian. Dibanding kelebihan yang dimiliki untuk menguji model secara utuh, maka penulis lebih memilih untuk tidak memasukkan variabel kontrol pada persamaan statistik No. (2). Oleh karena itu, variabel kontrol yang digunakan dalam penelitian ini hanya variabel yang diduga akan mempengaruhi kinerja perusahaan yaitu ukuran perusahaan (SIZE).
Hipotesis 1, 2, dan 3 diuji dengan menggunakan analisis regresi dengan bantuan software Process. Software ini memfasilitasi pengujian model mediasi moderasian dengan menampilkan indeks moderasi mediasian yang menjadi dasar penyimpulan hipotesis 3 . Persamaan untuk menguji hipotesis 1 dan 2 adalah sebagai berikut:

Risik0 $_{i, t 2}=\beta_{10}+\beta_{11}$ POSM $_{i, t 0}+\beta_{12}$ Lev $_{i, t 1}+\beta_{13}$ POSM*Lev $+\varepsilon$

Kinerja $_{i, t 2}=\beta_{20}+\beta_{21}$ POSM $_{i, t 0}+\beta_{22}$ Risk $_{i, t 2}+\beta_{23}$

Size ${ }_{i, t 2} \varepsilon$

Hipotesis 1, 2 terdukung bila, secara berturutan, $\beta_{13}(-), \beta_{22}(+)$ signifikan secara statistis pada $\alpha<5 \%$. Sedangkan hipotesis 3 terdukung bila indeks mediasi moderasian $\left(\beta_{13}{ }^{*} \beta_{22}\right)$ signifikan secara statistis pada $\alpha<5 \%$ (Hayes, 2015).

\section{HASIL DAN PEMBAHASAN}

Berikut ini adalah statistik deskriptif dari data yang akan digunakan untuk menguji hipotesis 1, 2, dan 3 yang bisa diolah sebelum dilakukan uji asumsi klasik. Jumlah sampel terdiri dari 38 firm event pengumumam POSM/POSK antara tahun 1999-2015. Sampel tersebut memenuhi persyaratan yang telah ditentukan pada poin 3A. Dari 38 sampel, 1 sampel outlier tidak diikutkan dalam pengujian.

Terkait dengan data variabel yang akan digunakan dalam penelitian ini, rerata jumlah opsi saham yang diberikan kepada TM adalah 138.532.088 dengan nilai terendah 4.000 .000 dan nilai tertinggi 980.000 .000 . Jumlah saham yang disiapkan dalam POSM tersebut maksimum adalah $5 \%$ dari jumlah saham yang ditempatkan dan disetor penuh, sehingga memudahkan perusahaan untuk melakukan penambahan modal tanpa melalui mekanisme HMETD. Kebijakan ini mengikuti peraturan Bapepam No. IX.D.4. 
Tabel 3 Statistik Deskriptif

\begin{tabular}{lrrrrr}
\hline Variabel & N & Minimum & Maksimum & Rerata & $\begin{array}{l}\text { Deviasi } \\
\text { Standar }\end{array}$ \\
\hline Opsi & 37 & .0000 & 1.0000 & .664944 & .3913649 \\
Lev & 37 & .0354 & 2.9942 & 1.129470 & .6924500 \\
Risk & 37 & .0000 & .3284 & .058703 & .0881867 \\
Size & 37 & 11.1512 & 14.4274 & 12.939351 & .9586438 \\
ROA & 37 & -.07 & .18 & .0574 & .05513 \\
ROE & 37 & .50 & .64 & .1514 & .18717 \\
IKK & 37 & -1.00 & 1.58 & .1216 & .42129 \\
Valid N (listwise) & 37 & & & & \\
\hline
\end{tabular}

Keterangan: OPSI:Rasio POSM yang digunakan oleh TM; Lev: Total hutang perusahaan dibagi total aset; Risk: Risiko yang diambil oleh TM yang diukur dengan kas yang dikeluarkan untuk investasi aktiva tetap; ROA, ROE, IKK = ukuran kinerja 1 tahun setelah perioda penggunaan opsi saham; Size: ukuran perusahaan

Informasi lain yang disajkan di Tabel 3 adalah bahwa dari 37 sampel, ada 7 sampel yang tidak menggunakan perioda tunggu sementara rata-rata perioda tunggu adalah 9 bulan. Terkait umur opsi saham, ada satu emiten yang hanya menyelenggarakan POSM selama satu bulan (AKSI), sementara rerata umur POSM adalah 48 bulan. Umur POSM terlama adalah 111 bulan yang diselenggarakan oleh MTDL. Dilihat dari sumber sahamnya, 58\% berasal dari penerbitan saham baru dan 39\% berasal dari saham dalam portepel, dan hanya 1 emiten (3\%) yang menggunakan saham treasuri.
Hipotesis 1 menguji pengaruh pengaruh struktur modal pada hubungan POSM dan perilaku risiko manajemen. Pengujina ini dilakukan untuk memastikan apakah TM yang bersedia menggunakan hak opsi sahamnya, yang secara otomatis menjadi pemilik saham perusahaan, akan berani mengambil tindakan berisiko dalam mengelola perusahaan. Apabila hasil pengujian signifikan positi, berarti teori yang menyatakan bahwa POSM akan menyelaraskan perilaku risiko TM dan pemegang saham dalam rangka memaksimalkan return adalah benar. Berikut ini adalah hasil pengujian $\mathrm{H} 1$.

Tabel 4 Hasil Uji Regresi Hipotesis 1

\begin{tabular}{|c|c|c|c|}
\hline & Coeff. & SE & $\mathrm{t}$ \\
\hline Constant & -.0249 & .0518 & -.4811 \\
\hline Posm & 1046 & .0674 & 1.5506 \\
\hline Lev & 1388 & .0570 & 2.4364 * \\
\hline Int_1 & 年. & .0649 & -2.5896 * \\
\hline R-sq & 1932 & & \\
\hline $\mathrm{F}$ & 2.6344 & & \\
\hline p.val & .0661 & & \\
\hline
\end{tabular}


Hasil pengujian pada tabel di atas menunjukkan bahwa kebersediaan TM untuk menggunakan hak opsi sahamnya tidak serta merta diikuti dengan kebijakan pengambilan kebijakan berisiko dalam mengelola perusahaan. Hal ini terlihat dari koefisien $\beta_{11}$ yang tidak signifikan. Kebijakan berisiko yang diambil oleh perusahaan tergantung pada seberapa besar utang perusahaan dalam struktur modal perusahaan. Koefisien $\beta 13$ yang merupakan interaksi antara opsi saham manajemen dan utang perusahaan menunjukkan arah negatif $(-0,1681)$ dan signifikan pada nilai p.value $<5 \% \quad(0,0142)$. Artinya, semakin besar utang perusahaan, TM akan semakin kurang berani mengambil kebijakan pengelolaan yang berisiko. Dalam penelitian ini, struktur utang adalah pemoderasi semu, yang ditunjukkan dengan signifikannya pengaruh besaran utang terhadap perilaku risiko TM (0,1388; signifikan pada p.value<5\%). Dengan demikian, hipotesis 1 dalam penelitian ini terdukung.

Hasil pengujian statistis di atas mengisyaratkan bahwa, mendukung Kim et al. (2017), pengambilan kebijakan manajemen dalam mengelola perusahaan tentu tidak dapat dilepaskan dari kondisi perusahaan. Ketika TM memutuskan untuk mengalokasikan sebagian sumber daya perusahaan untuk berinvestasi yang hasilnya tidak pasti, TM akan memastikan apakah investasi tersebut akan menggangu operasional perusahaan. Semakin tinggi strutur utang perusahaan, TM yang memperoleh insentif dalam bentuk opsi saham mempunyai kecenderungan untuk menurunkan hasrat pengambilan kebijakan perusahaan yang berisiko. Artinya, POSM tidak serta merta akan mendorong TM untuk menyelaraskan perilaku risiko TM dengan pemegang saham lainnya melainkan tergantung pada apakah kondisi perusahaan sebelum kebijakan tersebut dilaksanakan.

Hipotesis 2 dalam penelitian ini betujuan untuk menguji pengaruh perilaku risiko TM terhadap kinerja perusahaan. Teori portofolio moderen menyatakan bahwa ada keterkaitan antara tingkat risiko dan tingkat return investasi. Semakin besar tingkat risiko yang ditawarkan pada sebuah portofolio, diduga akan menghasilkan tingkat return yang semakin tinggi pula. Dalam kasus POSM, teori menduga bahwa program ini akan mendorong TM untuk bersedia mengambil kebijakan pengelolaan perusahaan pada tingkat risiko tertentu yang akan memberikan return terbesar pada pemegang saham. Hal ini karena setelah menggunakan hak opsi sahamnya, TM juga akan menjadi pemegang saham yang mempunyai kepentingan sama dengan pemegang lainnya yang bukan pengelola perusahaan. Berikut ini adalah hasil pengujian hipotesis 2. 
Tabel 5 Hasil Uji Regresi Hipotesis 2

Kinerja $_{i, 22}=\beta_{20}+\beta_{21}$ POSM $_{i, t 0}+\beta_{22}$ Risk $_{i, t 2}+\beta_{23}$ Size $_{i, t 2}+\varepsilon$

\begin{tabular}{|c|c|c|c|c|c|c|c|c|}
\hline \multirow{2}{*}{$\begin{array}{l}\text { Pengukur } \\
\text { Kinerja }\end{array}$} & \multirow[t]{2}{*}{$\mathrm{N}$} & \multirow[t]{2}{*}{ Model } & \multicolumn{3}{|c|}{$\begin{array}{l}\text { Unstandardized } \\
\text { Coefficients }\end{array}$} & \multirow[t]{2}{*}{$T$} & \multirow[t]{2}{*}{$F$} & \multirow{2}{*}{$\begin{array}{l}\text { Adj. } \\
\mathrm{R}^{2}\end{array}$} \\
\hline & & & & B & SE & & & \\
\hline \multirow[t]{4}{*}{$\overline{R O A}$} & 37 & Constant & $\beta_{20}$ & .0365 & .1293 & .2824 & 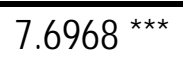 & 0,3582 \\
\hline & & Posm & $\beta_{21}$ & .0338 & .0214 & 1.5747 & & \\
\hline & & Risk & $\beta_{22}$ & 3903 & . 0991 & 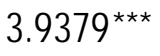 & & \\
\hline & & Aset & $\beta_{23}$ & -.0019 & .0102 & - 1855 & & \\
\hline \multirow[t]{4}{*}{ ROE } & 37 & Constant & $\beta_{20}$ & -.6570 & 4912 & -1.3374 & 3.9239 ** & 0,1959 \\
\hline & & Posm & $\beta_{21}$ & 1806 & .0815 & 2.2169 ** & & \\
\hline & & Risk & $\beta_{22}$ & .4802 & 3766 & 1.2752 & & \\
\hline & & Aset & $\beta_{23}$ & .0510 & .0387 & 1.3187 & & \\
\hline \multirow[t]{4}{*}{ IKK } & 37 & Constant & $\beta_{20}$ & -.0290 & 1.2424 & -.0233 & .8204 & -.0152 \\
\hline & & Posm & $\beta_{21}$ & .2202 & 2060 & 1.0688 & & \\
\hline & & Risk & $\beta_{22}$ & .9725 & .9525 & 1.0210 & & \\
\hline & & Aset & $\beta_{23}$ & -.0041 & .0978 & -.0418 & & \\
\hline
\end{tabular}

${ }^{*},{ }^{* \star},{ }^{* \star *}$ : Signifikan secara statistis pada $p$-value, berturut-turut, $<10 \%,<5 \%,<1 \%$

Tabel di atas merupakan hasil pengujian dengan menggunakan 3 pengukur kinerja yang berbeda yaitu kinerja keungan yang diwakili oleh ROA, ROE dan kinerja pasar yang diwakili oleh IKK. Secara umum, model yang diukur dengan kinerja keuangan menunjukkan nilai signifikansi pada nilai p.value $<5 \%$ $(\mathrm{ROA}=0,0005$ dan $\mathrm{ROE}=0,0168)$. Sementara pada model IKK tidak signifikan.

Pada model yang kinerja keuangan diukur dengan ROA menunjukkan bahwa tingkat risiko berpengaruh positif terhadap kinerja dengan nilai koefisien 0,3903 , signifikan pada nilai p.value $<5 \%(0,0004)$. Artinya, semakin tinggi tingkat risiko yang diambil TM dalam mengelola perusahaan, semakin tinggi pula tingkat return yang dicapai oleh perusahaan yang diukur dengan ROA. Namun demikian, pada model ini POSM dan ukuran perusahaan tidak terbukti berpengaruh terhadap kinerja perusahaan.

Pada model kedua, ketika kinerja diukur dengan ROE, hasilnya menunjukkan bahwa tingkat risiko tidak berpengaruh terhadap kinerja. Namun POSM berpengaruh positif terhadap kinerja dengan nilai koefesien sebesar 0,1806 , signifikan pada p.value $<5 \%(0,0336)$. Ukuran perusahaan yang direpresentasi dengan besaran aset perusahaan tidak terbukti signifikan berpengaruh terhadap Kinerja.

Pada model ketiga, ketika kinerja diukur dengan IKK yang merepresentasi kinerja saham perusahaan, hasilnya menunjukkan bahwa kebijakan berisiko yang diambil perusahaan tidak signifikan. Demikian halnya dengan POSM dan ukuran perusahaan.

Dari ketiga hasil yang menggunakan pengukur kinerja berbeda dapat disimpulkan bahwa Perilaku risiko TM hanya signifikan ketika diukur degan ROA. Hasil ini boleh jadi karena kebijakan berisiko yang digunakan dalam penelitian ini menggunakan pengukur besarnya nilai investasi pada aktiva tetap yang dilakukan oleh perusahaan. Pengukur ini mempunyai korelasi kuat dengan kinerja yang diukur dengan tingkat kembalian hasil investasi aset (ROA). Namun tidak demikian halnya ketika kinerja dikaitkan dengan ekuitas dan nilai saham 
perusahaan. Dari hasil ini penulis dapat menyimpulkan bahwa $\mathrm{H} 3$ terdukung hanya pada kinerja yang terkait dengan aset perusahaan.

Hipotesis 3 dalam penelitian ini menguji argumen bahwa POSM tidak berpengaruh langsung terhadap kinerja perusahaan, melainkan tergantung pada apakah program tersebut mampu mendorong TM untuk mengambil kebijakan pengelolaan perusahaan yang berisiko dalam rangka mendapatkan tingkat return yang lebih tinggi. Ketika TM telah menggunakan hak opsi sahamnya, idealnya mereka akan mempunyai kepentingan yang sama dengan pemegang saham lainnya yaitu return perusahaan yang menguntungkan.

Dari ketiga model yang diuji dalam penelitian ini (ROA, ROE, dan IKK), hasilnya menunjukkan bahwa hanya ketika kinerja diukur dengan ROA, POSM mampu mendorong TM untuk mengambil kebijakan pengelolaan berisiko dalam bentuk investasi aset yang selanjutnya meningkatkan kinerja perusahaan. Pengaruh mediasi moderasian ditunjukkan dengan nilai indeks sebesar -0,0656 yang signifikan secara statistis pada p.val $<5 \%$. Artinya, perilaku risiko TM memediasi pengaruh POSM terhadap kinerja. Namun, tidak demikian halnya ketika kinerja diukur dengan ROE dan IKK.

Dengan demikian, argumen teori keagenan (Jensen dan Meckling, 1976) bahwa POSM akan menjadi sarana penyelarasan kepentingan pemegang saham dan TM melalui penyelarasan perilaku risiko, tidak sepernuhnya terdukung dalam penelitian ini. Oleh karena POSM berkaitan dengan nilai saham perusahaan, secara teori, seharusnya kebijakan TM akan berimbas pada kinerja saham, yaitu IKK dan ROE. Namun demikian, dalam penelitian ini justru berimbas pada kinerja keuangan ROA. Penulis menduga bhawa hasil ini sensitif terhadap pengukur yang digunakan untuk mengukur kebijakan berisiki TM yaitu besaran investasi aset yang secara teori akan berasosiasi dengan kinerja yang melibatkan aset yaitu ROA.

\section{PENUTUP}

Kompensasi berbasis ekuitas dalam bentuk POSM adalah salah satu sarana yang dianggap tepat untuk menyelaraskan kepentingan antara prinsipal dan manajer (Jensen dan Meckling, 1976; Hall dan Liebman, 1998). Hal ini karena memasukkan POSM sebagai bagian dari penyusunan kontrak optimal akan mengikat utilitas ekpektasian eksekutif pada kesejahteraan prinsipal yang pada akhirnya akan menciptakan insentif bagi eksekutif untuk memaksimalkan nilai perusahaan (Jensen dan Murphy, 1990a, 1990b). Lebih lanjut, Jensen dan Murphy (1990a) menyatakan bahwa pengikatan kepentingan akan mengarahkan preferensi risiko manajer, yang diasumsikan penghindarrisiko, mendekati preferensi risiko prinsipal yang netral-risiko.

Penelitian ini bertujuan untuk menguji argumen teori keagenan bahwa pengaruh POSM terhadap kinerja bukanlah pengaruh langsung melainkan pengaruh tidak langsung melalui perilaku risiko TM. Artinya, penyelarasan kepentingan hanya akan terjadi kalau ada penyelarasan perilaku risiko. Penulis juga menguji bahwa perilaku berisiko TM juga akan dipengaruhi/tergantung pada kondisi perusahaan.

Hasil pengujian menunjukkan bahwa, mendukung hipotesis 1 , struktur modal perusahaan mempengaruhi pengambilan kebijakan berisiko TM. Semakin tinggi struktur modal perusahaan yang berasal dari pinjaman (utang), mengisyaratkan kecenderungan penurunan perilaku pengambilan risiko TM. Sementara untuk hipotesis kedua dan ketiga, hasil pengujian hanya terdukung bila kinerja perusahaan diukur menggunakan ROA, tetapi tidak untuk ROE dan IKK. Argumen teori keagenan, dengan demikian tidak terdukung sepenuhnya karena dari ketiga pengukur, hanya ada satu pengukur yang terdukung.

Pengadopsian POSM belum terlalu umum dilakukan oleh perusahaan yang 
terdaftar di BEI. Hal ini terlihat dari sedikitnya jumlah sampel yang memungkinkan untuk diuji dalam penelitian ini. Terlebih, banyak perusahaan yang tidak mengumumkan secara terpisah jumlah opsi yang diberika kepada karyawan dan TM, termasuk jumlah opsi yang mereka gunakan. Hal ini menjadi kendala untuk mengeksplorasi lebih lanjut penelitian di bidang ini. Seiring berjalannya waktu, penelitian selanjutnya dapat menambah jumlah sampel pengujian.

Hasil pengujian menunjukkan bahwa hipotesis 2 dan 3 hanya terdukung ketika kinerja diukur dengan ROA. Penulis menduga bahwa hasil ini sensitif dengan pengukur yang digunakan untuk mengukur kebijakan berisiko yang diambil oleh TM. Penelitian selanjutnya dapat menggunakan pengukur lain yang tidak secara spesifik akan condong memengaruhi salah satu hasil kinerja, misalnya besaran biaya riset dan pengembangan yang dikeluarkan perusahaan.

\section{UCAPAN TERIMA KASIH}

Penulis mengucapkan terima kasih kepada LP3M Universitas Muhammadiyah Yogyakarta yang telah mendanai penelitian ini.

\section{REFERENSI:}

Abdelaziz, E. M., L. Amine, \& C. Lanouar. 2011. Stock-Options and the Performance of CAC40 Listed Companies. International Journal of Economics and Finance, 3(1).

Anwar, A. 2006. Pengaruh Program Opsi Saham Karyawan (POSK) terhadap Kinerja dan Nilai Perusahaan: Studi Empiris pada BEJ (Master's thesis). Program Magister dan Sains FEB UGM. Tidak dipublikasi.

Astika, I.B.P. 2007. Perilaku Oportunistik Eksekutif dalam Pelaksanaan Program Opsi Saham (Dissertation). Program Magister Sain dan Doktor FE UGM.

Badan Pengawas Pasar Modal (BAPEPAM). (2009, Juni 21). Retrieved from http://www.bapepam.go.id/old/old/hukum/peraturan/index.htm.

Defusco, R., T. S. Zorn., \& R. Johnson. 1991. The Association between Executive Stock Option Plan Changes and Managerial Decision Making. Financial Management, 20, 36-43.

Echambadi, R., \& J.D. Hess. 2007. Mean-Centering Does Not Alleviate Collinearity Proble in Moderated Multiple Regression Models. Marketing Science, 26(3), 438-445.

Eisenhardt, K.M. 1989. Agency Theory: An Assessment and Review. The Academy of Management Review, 14(1), 57-74.

Fama, E. F. 1980. Agency Problem and the Theory of the Firm. Journal of Political Economy, 88(2), 288-307.

Guay, W. R. 1999. The Sensitivity of CEO Wealth to Equity Risk: An Analysis of The Magnitude and Determinants. Journal of Financial Economics, 53, 43-71.

Hall, B. J., \& K. J. Murphy. 2002. Stock Option for Undiversified Executives. Journal of Accounting and Economics, $33,3-42$.

Hambrick, D. C., \& P. A. Mason. 1984. Upper Echelons: The Organizations A Reflection of Its Top Managers. Academy of Management Review, 9, 193-206.

Hambrick, D.C., 2007. Upper Echelons Theory: An Update. Academy of Management Review, 32(2), 334-343.

Hanlon, M., S. Rajgopal., \& T. Shevlin. 2003. Are Executive Stock Options Associated With Future Earnings? Journal of Accounting \& Economics, 36(1-3), 3-43.

Hayes, A.F. 2015. An Index and Test of Linear Moderated Mediation. Multivariate Behavioral Research, 50(1), 122.

Huddart, S., \& M. Lang. 1996. Employee Stock Option Exercises. An Empirical Analysis. Journal of Accounting and Economics, 21, 5-43.

Hutchinson M., \& F. A. Gul. 2006. The Effects of Executive Share Options and Investment Opportunities on Fir' Accounting Performance: Some Australian Evidence. The British Accounting Review, 38, 277-297. 
Indjejikian, R. J. 1999. Performance Evaluation and Compensation Research: An Agency Perspective. Accounting Horizon, 13(2), 147-157.

Jensen, M., \& K. J. Murphy. 1990. Performance Pay and Top-Management Incentives. Journal of Political Economy, 98(2), 225-264.

Jensen, M., \& W. Meckling. 1976. Theory of the Firm: Managerial Behavior, Agency Costs, and Ownership Structure. Journal of Financial Economics, 3(4), 305-360.

Jogiyanto, H.M. (2007). Teori Portofolio dan Analisis Investasi. Yogyakarta: BPFE.

Kato, H. K., M. Lemnomon, M. Luo, \& J. Schallheim. 2005. An Empirical Examination of the Costs and Benefits of Executive Stock Options: Evidence from Japan. Journal of Financial Economics, 78, 435-461.

Kim, K., S. Patro, \& R. Pereira. 2017. Option Incentives, Leverage, and Risk-Taking. Journal of Corporate Finance, 43, 1-18.

Kresnawati, E. 2009. Kinerja Perusahaan pada Perioda Pengadopsian Opsi Saham Karyawan dengan Evaluasi Kinerja Relatif. Working paper.

Kresnawati, E., Z. Baridwan, Suwardjono, \& S. Warsono. 2016. Pengaruh Program Opsi Saham Manajamen terhadap Kinerja Perusahaan: Analisis Teori Keagenan dan House Money Effect. Lampung: Simposium Nasional Akuntansi.

Murphy , K. J. 2002. Explaining Executive Compensation: Managerial Power vs the Perceived Cost of Stock Options. University of Chicago Law Review, 69, 847-869.

Nyberg, A., I.S. Fulmer, B. Gerhart., \& M. A. Carpenter. 2010. Agency Theory Revisited: CEO Returns and Shareholder Interest Alignment. Academy of Management Journal, 53(5), 1029-1049.

Sautner, Z., \& M. Weber. 2005. Stock Options and Employee Behavior. Working paper.

Wiratma, T, \& R. S. Kristanto. 2010. Analisis Pengaruh ESOP (Employee Stock Option Ownership Program) terhadap Kinerja Perusahaan di Bursa Efek Indonesia. Prestasi, 6(1), 120-135. 